\title{
Faktor-faktor yang Mempengaruhi Volume Ekspor Kopi dari Kabupaten Aceh Tengah ke Amerika Serikat
}

\section{Factors That Influence Coffee Export Volume from Central Aceh Regency to United States}

\author{
Afriamah, Zulkarnain Lubis, \& Mitra Musika Lubis
}

Program Studi Agribisnis Universitas Medan Area

Diterima: April 2021 Direview: April 2021 Disetujui: April 2021

*Corresponding Email: Afriamah@gmail.com

\begin{abstract}
Abstrak
Indonesia adalah salah satu produsen kopi terbesar dunia, hal ini dapat dilihat dari jumlah ekspor dari Indonesia untuk ekspor komoditas kopi. Dalam beberapa tahun terakhir, berbagai perusahaan asing telah melakukan ekspansi besar-besaran untuk mendapatkan kopi Gayo dari Aceh Tengah dan Bener Meriah. Tujuan dari penelitian ini adalah untuk mengetahui faktor-faktor yang mempengaruhi volume ekspor kopi Gayo dari Kabupaten Aceh Tengah ke Amerika Serikat. Metode pengumpulan data menggunakan metode dokumenter yaitu metode pengumpulan data dengan menyelidiki dan mempelajari dokumen sesuai dengan variabel dalam model penelitian pada periode 20132017. Data yang dikumpulkan adalah data sekunder. Metode analisis yang digunakan adalah regresi linier berganda dengan metode Ordinary Least Square (OLS). Dari penelitian menggunakan analisis regresi linier berganda didapatkan bahwa variabel yang signifikan terhadap permintaan ekspor kopi Gayo dari Amerika Serikat adalah harga kopi dunia. Sedangkan produksi kopi Gayo dalam negeri, nilai tukar Dolar terhadap Rupiah dan harga kopi Gayo luar negeri tidak signifikan terhadap permintaan ekspor kopi Gayo ke Amerika Serikat.
\end{abstract}

Kata Kunci: ekspor; harga; kopi gayo; kurs; permintaan

\begin{abstract}
Indonesia is one of the world's largest coffee producers, it can be seen from the amount of exports from Indonesia for coffee export. In the past few years, several companies have carried out massive expansion to get Gayo coffee from Central Aceh Regency and Bener Meriah. The purpose of this study was to analysis what factors influence the volume of Gayo coffee exports from Central Aceh Regency to the United States. The data collection method using the documentary method is the data obtained and viewed by the document in accordance with the variables in the research model in the period 2013-2017. Data collected is secondary data. The analytical method used is multiple linear regression with the method used is the Ordinary Least Square (OLS) Method. From the research using multiple linear regression analysis obtained that variables which have significant effect to the export demand of Gayo Coffee from the United States is Global Coffee Prices. While the production of domestic Gayo coffee, the exchange rate of dollars against the rupiah and the price of foreign Gayo coffee are not significant to the demand for export of Gayo coffee to the United States.
\end{abstract}

Keywords: demand; exchange rate; export; gayo coffee; price

How to Cite: Afriamah, Lubis, Z \& Lubis, M.M (2021). Faktor-faktor yang Mempengaruhi Volume Ekspor Kopi dari Kabupaten Aceh Tengah ke Amerika Serikat. Jurnal Agriuma. 3 (1): 1-8. 


\section{PENDAHULUAN}

Sektor pertanian Indonesia memegang peran strategis dalam pembangunan perekonomian nasional dan menjadi sektor andalan serta mesin penggerak pertumbuhan ekonomi. Hal ini dikarenakan sektor pertanian tidak hanya memberikan kontribusi terhadap Produk Domestik Bruto (PDB) Indonesia namun juga merupakan penghasil devisa yang relatif besar terhadap pertumbuhan perekonomian Indonesia.

Indonesia merupakan salah satu negara agraris penghasil kopi terbaik dan terbesar dunia. Hal ini dapat dilihat dari jumlah ekspor dari Indonesia yang dilakukan oleh perusahaan eksportir komoditas kopi. Beberapa tahun terakhir, berbagai perusahaan asing telah melakukan ekspansi besar-besaran untuk mendapatkan kopi arabika dari Aceh Tengah dan Bener Meriah.

Indonesia merupakan salah satu negara berkembang yang menganut sistem perekonomian terbuka kecil, artinya terdapat perdagangan internasional, yaitu perdagangan yang melakukan ekspor tetapi bukan sebagai pembuat harga (price maker) sehingga tidak terlepas dari perdagangan luar negeri. Negara yang melakukan perdagangan luar negeri dapat meningkatkan pendapatannya dengan mengekspor bahan baku mentah, barang setengah jadi, maupun barang yang sudah jadi atau siap pakai.

Dalam perdagangan internasional, Pemerintah Republik Indonesia telah menetapkan beberapa peraturan dan kebijakan terkait perdagangan luar negeri. Kebijakan perdagangan luar negeri disusun dan ditetapkan oleh Menteri Perdagangan. Provinsi Aceh memiliki kewenangan dalam mengatur dan mengelola sistem pemerintah daerah, namun dalam hal kebijakan perdagangan luar negeri tetap dilaksanakan oleh pemerintah pusat. Hal ini terkait dengan perjanjian Internasional, jangkauan operasional bersifat nasional yang memerlukan koordinasi antar instansi terkait tingkat nasional maupun internasional. Pengelompokkan barang-barang ekspor diatur dalam Keputusan Menteri Perindustrian dan Perdagangan Nomor 558/MPP/Kep/12/1998 tanggal 4 Desember 1998 tentang ketentuan umum di bidang ekspor sebagaimana telah beberapa kali diubah terakhir dengan Peraturan Menteri Perdagangan Nomor 87/M-DAG/PER/10/2015. Dalam pengaturan ekspor terdiri dari barang yang diatur ekspornya, barang yang diawasi ekspornya, barang yang dilarang dan barang yang bebas ekspornya. Kopi merupakan komoditi yang diatur ekspornya, sebagaimana yang tertera dalam Peraturan Menteri Perdagangan Republik Indonesia Nomor 27/M-DAG/PER/7/2008 Tentang Ketentuan Ekspor Kopi.

Provinsi Aceh merupakan salah satu provinsi di Indonesia yang memiliki potensi sumber daya alam baik berupa sumber daya minyak dan gas bumi maupun dari sektor pertanian, perkebunan, kehutanan, perikanan dan kelautan. Komoditi kopi merupakan salah satu komoditi ekspor yang memberikan kontribusi dalam devisa negara dan merupakan salah satu komoditi unggulan. Saat ini Provinsi Aceh tergolong salah satu daerah produsen kopi Arabika dan Robusta terbesar di Indonesia (Zikria, 2020). Sektor perkebunan merupakan sektor unggulan di Kabupaten Aceh Tengah yang memberikan kontribusi terbesar terhadap pembentukan Produk Domestik Regional Bruto (PDRB). Komoditi perkebunan yang menjadi unggulan adalah kopi. Luas perkebunan kopi di Kabupaten Aceh Tengah mencapai 48.000 ha dari luas wilayah kabupaten dengan jumlah produksi kopi (biji hijau atau green bean) rata-rata sebesar 25.187 ton/tahun. Jumlah produksi kopi Gayo kurun waktu 2013-2017 datat dilihat pada tabel 1. 
Tabel 1. Produksi Kopi Arabika Gayo Kabupaten Aceh Tengah Tahun 2013-2017

\begin{tabular}{cc}
\hline Tahun & $\begin{array}{c}\text { Produksi Kopi } \\
\text { Arabika Gayo/Ton }\end{array}$ \\
\hline 2013 & 253.699 \\
2014 & 25.926 \\
2015 & 268.509 \\
2016 & 16.482 \\
2017 & 29.238 \\
\hline
\end{tabular}

Sumber : Badan Pusat Statistik Kabupaten Aceh Tengah (Diolah)

Aceh Tengah merupakan salah satu pengekspor kopi terbesar terutama ke Amerika Serikat yang mencapai 703.200 kilo gram dari total ekspor sepanjang Januari hingga Desembar 2017, selain ke Amerika Serikat, ekspor kopi Arabika Gayo juga menembus Australia mencapai 57.600 $\mathrm{Kg}$, Kanada $268.800 \mathrm{Kg}$, dan Jerman $36.000 \mathrm{Kg}$. Permintaan ekspor kopi Gayo selalu meningkat bahkan tidak mencukupi permintaan negara pengimpor terhadap 'specialty' grade 1 (satu) dan grade 2 (dua). Jenis kopi yang diekspor masih dalam bentuk biji mentah atau sering disebut kopi biji (green bean) (KBQ Baburayyan).

Tabel 2. Volume Ekspor Kopi Gayo Provinsi Aceh Tahun 2013-2017

\begin{tabular}{cc}
\hline Tahun & Volume Ekspor (Ton) \\
\hline 2013 & 1.669 \\
2014 & 2.222 \\
2015 & 1.670 \\
2016 & 1.531 \\
2017 & 1.065 \\
\hline Koperasi Baitul Qiradh Baburayyan (Diolah)
\end{tabular}

\section{Tinjauan Pustaka}

Tanaman kopi adalah pohon kecil yang bernama Perpugenus Coffea, sp dan familia Rubiaceace serta jenis Coffea. Kopi bukan produk homogen, ada banyak varietas dan beberapa cara pengolahannya (Spillane, 1990). Perdagangan internasional adalah perdagangan yang dilakukan oleh penduduk suatu negara dengan penduduk negara lain atas dasar kesepakatan bersama. Penduduk yang dimaksud dapat berupa antar perorangan (individu dengan individu), antara individu dengan pemerintah suatu negara atau pemerintah suatu negara dengan pemerintah negara lain (Lindert, 1993).

Ekspor merupakan suatu aktivitas menjual produk dari suatu negara ke negara lain. Kunci perdagangan internasional adalah teori keunggulan komparatif. Prinsip keunggulan komparatif menunjukkan bahwa spesialisasi akan menguntungkan semua negara meskipun ada negara yang secara mutlak lebih efisien dalam memproduksi semua barang dibandingkan negara lainnya. Dalam teori modern mengenai perdagangan internasional dikenal teori Hecsher dan

Ohlin (H-O). Teori ini disebut juga teori ketersediaan faktor (factor proportion theory). Teori H-O menggunakan asumsi $2 \times 2 \times 2$ dalam arti sebagai berikut perdagangan internasional terjadi 
antara dua negara, masing-masing negara memproduksi dua macam barang yang sama, masingmasing negara menggunakan dua macam faktor produksi yaitu tenaga kerja dan mesin tetapi dengan jumlah/proporsi yang berbeda.

\section{METODE PENELITIAN}

Data sekunder yang digunakan adalah data yang dicatat secara sistematis yang berbentuk data runtut waktu (time series data). Dalam penelitian ini digunakan data tahun 2013-2017 yang diperoleh dari berbagai sumber antara lain jumlah ekspor kopi Arabika Gayo selama kurun waktu 5 tahun diperoleh dari perusahaan eksportir Kopi Gayo yaitu KBQ Baburayyan, data harga kopi dunia diperoleh dari ICO (International Coffee Organization), luas areal, produksi komoditi kopi Arabika dan jumlah petani perkebunan rakyat, tahun 2016 diperoleh dari dinas kehutanan dan perkebunan Provinsi Aceh. Sedangkan data tentang kurs Dollar Amerika Serikat terhadap Rupiah Indonesia dinyatakan dalam Rupiah per Dollar diperoleh dari Bank Indonesia.

\section{HASIL DAN PEMBAHASAN}

\section{Uji Penyimpangan Asumsi Klasik}

Dengan menggunakan uji penyimpangan Asumsi Klasik tidak terjadi Autokorelasi dengan hasil yang diperoleh adalah nilai DW observasi terletak pada daerah $\mathrm{du}<\mathrm{d}<4$-du, daerah tidak menolak Ho. Multikorelasi hasil perhitungan nilai toleransi menunjukkan bahwa nilai toleransi pada variabel bebas lebih besar dari 0,10. Maka, dapat disimpulkan bahwa tidak terjadi multikorelasi dalam model regresi dan Uji Heterokedastisitas dengan nilai sig lebih besar dari 0,05 maka dapat disimpulkan bahwa tidak terjadi Heterokedastisitas pada keempat variable bebas tersebut.

\section{Uji Statistik}

Dari uji $\mathrm{F}$ dapat dilhat bahwa dari perhitungan diketahui bahwa Prob. sign 0,006 menunjukan bahwa secara bersama-sama (uji serentak) keempat variabel independen produksi kopi Gayo domestik, nilai tukar dolar terhadap rupiah, harga kopi dunia, dan harga kopi Gayo di luar negeri terdapat pengaruh terhadap volume ekspor kopi Indonesia dari Amerika Serikat. Hal ini sesuai dengan nilai sig sebesar 0,006 < 0,05 maka H0 ditolak dan H1 diterima.

Dari Uji $\mathrm{F}$ dapat dilihat bahwa pada umumnya permintaan ekspor kopi untuk industri makanan, minuman dan kosmetik. 
1. Uji T

\begin{tabular}{|c|c|c|c|c|c|c|}
\hline & \multicolumn{6}{|c|}{ Coefficients } \\
\hline & \multirow{2}{*}{ Model } & \multicolumn{2}{|c|}{ Unstandardized Coefficients } & \multirow{2}{*}{\begin{tabular}{|c}
$\begin{array}{c}\text { Standardized } \\
\text { Coefficients }\end{array}$ \\
Beta \\
\end{tabular}} & \multirow{2}{*}{$\mathrm{T}$} & \multirow{2}{*}{ Sig. } \\
\hline & & B & Std. Error & & & \\
\hline \multirow{5}{*}{1} & (Constant) & 122952,368 & 82026,958 & & 1,499 & 140 \\
\hline & $\begin{array}{c}\text { Produksi } \\
\text { Kopi Gayo } \\
\text { Domestik }\end{array}$ & 001 & 001 & ,114 & ,776 & ,441 \\
\hline & Kurs &,- 076 & 052 &,- 221 & $-1,478$ & , 145 \\
\hline & $\begin{array}{c}\text { Harga Kopi } \\
\text { Dunia }\end{array}$ & 7,113 & 2,419 & ,406 & 2,941 & 005 \\
\hline & $\begin{array}{l}\text { Harga Kopi } \\
\text { Gayo Luar } \\
\text { Negeri }\end{array}$ & ,276 & 1,031 & ,036 & ,267 & ,790 \\
\hline
\end{tabular}

a. Variabel Produksi Kopi Gayo Domestik

Variabel produksi kopi Gayo domestik angka sign nilai probabilitas signifikan 0,05 $(\alpha=$ $5 \%)$ dengan nilai signifikansi $(0,441)>$ dari $0,05(\alpha=5 \%)$, yang berarti bahwa variabel produksi kopi Gayo domestik tidak berpengaruh terhadap volume ekpor kopi ke Amerika Serikat. Berdasarkan hasil tersebut, menunjukkan bahwa produksi kopi Gayo tidak berpengaruh terhadap volume ekspor. Koefisien produksi kopi Gayo (X1) sebesar 0,001 artinya, setiap kenaikan Produksi kopi Gayo Domestik sebanyak 1 ton maka akan menaikkan Volume ekspor sebesar 0,001 ton.

Sebagian besar produk kopi Gayo merupakan produk ekspor dan negara-negara pengimpor telah menetapkan food safety yang sangat ketat. Hal tersebut bukan serta merta ditetapkan oleh pihak pengimpor melainkan telah ditetapkan oleh FDA (Food and Drug Administration) dan ICO (International Coffee Organization). Khususnya pada penelitian ini negara pengimpor adalah Amerika Serikat yang sangat ketat melindungi hak-hak konsumen kopi untuk menghindari terjadinya hal-hal yang tidak diinginkan.

b. Variabel Nilai Tukar Dolar Terhadap Rupiah

Variabel nilai tukar dolar terhadap rupiah angka sign nilai probabilitas signifikan 0,05 ( $\alpha=$ $5 \%)$ dengan nilai signifikansi $(0,145)>$ dari $0,05(\alpha=5 \%)$ yang berarti bahwa variabel nilai tukar dolar terhadap rupiah tidak berpengaruh terhadap volume ekspor kopi Gayo ke Amerika Serikat. Hasil tersebut menunjukkan bahwa nilai tukar dollar terhadap rupiah tidak berpengaruh terhadap volume ekspor. Koefisien nilai tukar dollar terhadap rupiah $\left(\mathrm{X}_{2}\right)$ sebesar -0,076 artinya, setiap kenaikan nilai tukar dollar terhadap rupiah sebanyak 1 dollar maka akan menurunkan volume ekspor sebesar 0,076 ton. 
Nilai mata uang domestik terhadap mata uang asing dinilai lebih tinggi daripada nilai sebelumnya sebaliknya apabila exchange rate atau kurs valuta asing turun berarti mata uang domestik terhadap mata uang asing dinilai lebih rendah daripada sebelumnya. Dengan demikian jika exchange rate naik, berarti harga barang impor lebih rendah daripada sebelumnya sehingga jumlah barang impor yang diminta akan naik.

c. Variabel Harga Kopi Dunia

Variabel harga kopi dunia terhadap angka sign nilai probabilitas signifikan $0,05(\alpha=5 \%)$ dengan nilai signifikansi $(0,005)<$ dari $0,05(\alpha=5 \%)$ yang berarti bahwa variabel harga kopi dunia mempengaruhi volume ekspor kopi Gayo ke Amerika Serikat. Hasil tersebut menunjukkan bahwa harga kopi dunia berpengaruh terhadap volume ekspor. Koefisien harga kopi dunia $\left(\mathrm{X}_{3}\right)$ sebesar 7,113 artinya, setiap kenaikan harga kopi dunia sebanyak 1 dollar maka akan menaikkan volume ekspor sebesar 7,133 ton.

Harga kopi Gayo dalam penelitian ini tidak signifikan yang menerangkan bahwa harga kopi Gayo yang cukup tinggi tidak menjadi masalah yang berarti bagi Amerika Serikat untuk tetap melakukan impor produk kopi Gayo.

d. Variabel Harga Kopi Gayo di luar negeri

Variabel harga Kopi Gayo diluar negeri terhadap angka sign nilai probabilitas signifikan $0,05(\alpha=5 \%)$ dengan nilai signifikansi $(0,790)>$ dari $0,05(\alpha=5 \%)$ yang berarti bahwa kopi Gayo di luar negeri tidak berpengaruh terhadap volume ekspor kopi Gayo ke Amerika Serikat. Hasil tersebut menunjukkan bahwa harga kopi Gayo luar negeri berpengaruh terhadap volume ekspor. Koefisien harga kopi Gayo $\left(\mathrm{X}_{4}\right)$ sebesar 0,276 artinya, setiap kenaikan harga kopi Gayo di luar negeri sebanyak 1 dollar maka akan menaikkan volume ekspor sebesar 0,278 ton.

Harga kopi Gayo dalam penelitian ini tidak signifikan yang menerangkan bahwa harga kopi Gayo yang cukup tinggi tidak menjadi masalah yang berarti bagi Amerika Serikat untuk tetap melakukan impor pada produk kopi Gayo.

\section{SIMPULAN}

Kesimpulan yang dapat diambil dari penelitian ini adalah bahwa Kabupaten Aceh Tengah merupakan salah satu pengekspor kopi Gayo terbesar terutama ke Amerika Serikat yang mencapai 3,15 juta Kg dari total ekspor. Variable produksi kopi Gayo domestik, nilai tukar mata uang (kurs) dolar terhadap rupiah dan harga kopi arabika gayo luar negeri, tidak signifikan terhadap permintaan ekspor kopi Indonesia terhadap Amerika Serikat. Sedangkan variabel yang signifikan terhadap permintaan ekpor kopi Indonesia terhadap Amerika Serikat adalah harga kopi dunia.

\section{DAFTAR PUSTAKA}

Amaravathi, M. (2014). Indian Coffee Production and Export Destinations: An Overview. 3(10). October 2014.

Anggraini, D. (2006). Analisis Faktor-faktor yang Mempengaruhi Permintaan Kopi Indonesia dari Amerika Serikat dalam Jangka Panjang Tahun 1975-2004. Semarang: Program Pascasarjana Universitas Diponegoro.

Asosiasi Eksportir dan Industri Kopi Indonesia (AEKI). (2017). Ekspor Kopi. http://www.aekiaice.org/page/ekspor/id.diakses 4 April 2018 pukul 02:28 am. 
Baroh, I. (2014). Indonesian Coffee Competitiveness in the International Market: Review from the Demand Side. International Journal of Agriculture Innovations and Research, 3(2), ISSN (Online) 2319-1473.

BPS. (2014). Aceh Tengah dalam Angka. Takengon: Badan Pusat Statistik.

BPS. (2017) . Aceh Tengah dalam Angka. Takengon: Badan Pusat Statistik.

Boediono. (2001). Ekonomi Makro. Edisi ke 4. Yogyakarta : BPFE.

Chandra, D. (2013). Indonesian Robusta Coffee Trade Prospects in The International Markets. 1(1).

Darhyati, AT. (2017). Impact of Non-Tariff Measure on Indonesian Cacao Exports. International Journal of Agriculture System 5(2), Dec 2017.

Dinas Perindustrian Perdagangan Koperasi dan UMKM Aceh dalam Angka. Beberapa tahun terbitan.

Gujarati, D.N. (2007). Dasar-dasar Ekonometrika. Edisi ketiga. Jilid 2, Jakarta: Erlangga.

Hia, E. (2013). Faktor-faktor yang Mempengaruhi Ekspor Kopi Arabika di Sumatera Utara Tahun 2002-2012. Medan: Skripsi Program Studi Agribisnis USU.

Hong, T. (2016). Effects of Exchange Rate and World Prices on Export Price of Vietnamese Coffee. International Journal of Economics and Financial Issues. 6(4).

Krugman, P.R., and Obstfeld. (2005). Ekonomi Internasional Teori dan Kebijakan. Jakarta: PT. Indek Kelompok Gramedia.

Lindert. (1993). Ekonomi Internasional. Edisi ke 7. Jakarta: Erlangga.

Mankiw, N. Gregory. (1996). Teori Makro Ekonomi. Edisi ke 4. Terjemahan Imam Nurmawan, Jakarta: Erlangga,

Marbun, S. (2006). Analisis Faktor-faktor yang Mempengaruhi Ekspor Non Migas Indonesia Tahun 19702004. Medan: Program Pascasarjana IESP USU.

Nopriandi, R. (2017). Analisis Ekspor Kopi Indonesia 2010-2014. Jurnal Paradigma Ekonometrika. 12(1),

Novirin. (1999). Ekonomi Internasional. Jilid ke 3. Yogyakarta: BPFE Yogyakarta.

Panggabean, E. (2011). Buku Pintar Kopi. Edisi pertama. Jilid 1, Jakarta: Agromedia.

Perseveranda. (2005). Analisis Faktor-faktor yang Mempengaruhi Permintaan Kopi Daerah Nusa Tenggara Timur oleh Jepang dalam Jangka Pendek dan Jangka Panjang Tahun 1974-2003. Semarang: Tesis Program Pasca Sarjana Universitas Diponegoro.

Puspita, R. (2015). Pengaruh Produksi Kakao Domestik, Harga Kakao Internasional, dan Nilai Tukar terhadap Ekspor Kakao Indonesia ke Amerika Serikat. Jurnal Administrasi Bisnis. 27(1) Oktober 2015.

Rifin, A. (2013). Competitiveness of Indonesia's Cocoa Beans Export in the World Market. International Journal of Trade, Economics and Finance, 4(5).

Sadono, S. (2004). Makro Ekonomi Teori Pengantar. Edisi ke 3. Jakarta: PT. Raja Grafindo Persada.

Salvatore, D. (1997). Ekonomi Internasional. Edisi ke 5. Bandung: PT. Gelora Aksara Pratama.

Samuelson. (1997). Ekonomi. Edisi ke 12. Jakarta: PT. Erlangga.

Soviandre, E. (2014). Faktor-Faktor yang Mempengaruhi Volume Ekspor Kopi dari Indonesia ke Amerika Serikat Tahun 2010-2012.

Spilane. (1990). Komoditi Kopi: Peranannya dalam Perekonomian Indonesia. Terbitan Pertama. Jakarta: Kanisius.

Statistik Perkebunan Indonesia Komoditas Kopi dalam Angka. Jakarta. Beberapa tahun terbitan.

Raharja, P. (1999). Teori Ekonomi Mikro. Edisi ke 4. Jakarta: Lembaga Penerbit Fakultas Ekonomi Universitas Indonesia. 
Afriamah, Zulkarnain Lubis, \& Mitra Musika Lubis, Faktor-faktor yang Mempengaruhi Volume Ekspor Kopi dari Kabupaten Aceh Tengah ke Amerika Serikat

Tambunan. (2001). Perekonomian Indonesia (Kajian Teoritis dan Analisis Empiris). Jakarta. Ghalia Indonesia.

Zikria, V. (2020). Area Analysis of Commodity and Contribution of Coffee to Regional Development in Central Aceh Regency. Jurnal Social Economic of Agriculture, 9(2), 92-100. 